\title{
PERFIL DA DISCIPLINA DE METODOLOGIA CIENTÍFICA NOS CURSOS DE ODONTOLOGIA DO BRASIL
}

Karin NOGA; Fernanda Adamy BARRETO; Cassius Carvalho TORRES-PEREIRA

A disciplina de Metodologia Científica visa formar profissionais capazes de planejar e conduzir investigações enriquecendo seus conhecimentos. O ensino pretende desenvolver nos alunos o pensamento científico, reflexivo e crítico, tornando-o capaz de observar, analisar, criticar e buscar informações sobre os problemas da realidade, a fim de escolher alternativas, apresentar e executar soluções embasadas na análise. Essa pesquisa tem por objetivos analisar as disciplinas de Metodologia Científica ministradas nos 189 cursos de graduação de Odontologia do Brasil, com base na carga horária, conteúdo, estratégias de ensino e de avaliação utilizadas, titulação do corpo docente, entre outros. Para tanto, enviou-se um questionário on-line para os docentes da disciplina. A amostra foi constituída de dados fornecidos pelos docentes que responderam ao questionário. Concluiu-se que a nomenclatura da disciplina, assim como a etapa do curso em que ela é ministrada, sofrem grandes variações. As unidades didáticas abordam, na maioria dos casos, normas da ABNT, conhecimento científico, ética em pesquisa, TCC, bioestatística, entre outros. Embora o conteúdo tenha sido considerado satisfatório, de acordo com HARRISON et al (1991) é irreal esperar que os estudantes retenham todo o conhecimento aprendido se esse aprendizado não for reforçado subseqüentemente em outras experiências. 